\title{
EKONOMICZNE I ORGANIZACYJNE ZMIANY W GOSPODARSTWACH MLECZNYCH NALEŻACYCH DO EUROPEJSKIEGO STOWARZYSZENIA PRODUCENTÓW MLEKA
}

\author{
Ewa Koloszycz \\ Katedra Zarządzania Przedsiębiorstwami Zachodniopomorskiego \\ Uniwersytetu Technologicznego w Szczecinie \\ Kierownik Katedry: Prof. dr hab. Michał Świtlyk
}

\begin{abstract}
Słowa kluczowe: zarządzanie stadem, koszty produkcji mleka, próg rentowności Key words: herd management, milk production costs, breakeven point

S y n o p s i s. W opracowaniu scharakteryzowano zmiany, które zaszły w gospodarstwach wyspecjalizowanych w produkcji mleka w okresie przed reformą rynku mleka w Europie i po niej. Do badań wybrano 124 gospodarstwa należące do Europejskiego Stowarzyszenia Producentów Mleka (EDF), które w latach 2012-2016 uczestniczyły w analizach kosztów produkcji mleka. Wyniki badań wskazują, że we wszystkich grupach analizowanych gospodarstw nastąpił wyraźny wzrost produkcji, wynikający zarówno ze wzrostu wielości stad krów, jak i z poprawy wydajności mlecznej. Zaobserwowano wzrost intensywności wykorzystania ziemi i pracy, a także pogorszenie produktywności kapitału zaangażowanego w produkcję mleka. Największe różnice między grupami w ponoszonych kosztach produkcji mleka były w kosztach alternatywnych $\mathrm{i}$ amortyzacji. Niekorzystna sytuacja cenowa na rynku w 2016 r. sprawiła, że całkowite koszty produkcji mleka były niższe od cen mleka zaledwie w $12 \%$ analizowanych gospodarstwach.
\end{abstract}

\section{WPROWADZENIE}

Przetrwanie gospodarstw rolnych na rynku wymaga ciągłego dostosowywania ich działalności do zmieniającego się otoczenia. Za jedno z najważniejszych działań wychodzących naprzeciw tym zmianom uważa się zwiększenie poziomu profesjonalizacji produkcji rolnej dzięki specjalizacji lub dywersyfikacji [Krammer i in. 2012]. Może to prowadzić do koncentracji produkcji i przejawiać się w zwiększeniu wolumenu wytwarzanego mleka w tych gospodarstwach [Brodzińska 2016]. Deregulacja europejskiego rynku mleka umożliwiła m.in. zmiany $\mathrm{w}$ poziomie wsparcia tej produkcji w poszczególnych krajach członkowskich, co negatywnie wpływa na równe warunki konkurencji na rynku [Grochowska 2017]. Wyraźne zwiększenie produkcji, nastąpiło zwłaszcza w krajach, w których chów bydła mlecznego oraz produkcja mleka są jedną z najważniejszych gałęzi produkcji rolniczej. Wzrost ten przekroczył oczekiwania Komisji Europejskiej, która w prognozach nie doszacowała wielkości skupu o około $3 \mathrm{mln}$ ton mleka w 2015 r. [European 
Commission 2014]. Dodatkowo wprowadzenie embarga w handlu z Rosją oraz zwiększenie produkcji w krajach poza Europą, zaliczanych do największych producentów mleka (Indie, Pakistan, Stany Zjednoczone itp.) skutecznie ograniczyło możliwości zbytu nadprodukcji mleka na rynku światowym. W konsekwencji oddziaływania wielu czynników średnia cena mleka na światowym rynku w 2015 r. była niższa o około 34\% w porównaniu z rokiem 2014 r. [Hemme 2016, s. 17]. Rynek europejski doświadczył w lipcu 2016 r. spadku cen mleka do poziomu 25,68 euro/100 kg mleka surowego. Był to największy spadek cen od 2009 r., a ich poziom był wyższy zaledwie o około 5\% w porównaniu z 2009 r. [European Commission 2017]. Niesprzyjająca sytuacja cenowa, rządowe programy krajowe (np. w Niemczech) oraz zachęty finansowe ze strony przetwórców, skłaniające rolników do zmniejszenia ilości wytwarzanego mleka doprowadziły do zahamowania wzrostu produkcji w 18 krajach z 28 w UE, w tym w 12 państwach zaobserwowano spadek produkcji [Hemme 2017, s. 68]. Efektem oddziaływania wszystkich tych czynników było pogorszenie sytuacji ekonomicznej gospodarstw, która zależy od ceny kształtującej się zgodnie z trendami globalnymi [Kołoszycz 2016] oraz od kosztów wytworzenia produktu. Z perspektywy długookresowego rozwoju gospodarstwa przewaga nad konkurentami powinna zostać osiągnięta dzięki umiejętnej konfiguracji zasobów wykorzystywanych w procesie produkcyjnym w gospodarstwie, a nie stanowić wyniku krótkookresowego wzrostu cen na rynku. Racjonalne wykorzystywanie zasobów w gospodarstwie ma swoje odzwierciedlenie w organizacji produkcji oraz w poziomie kosztów ponoszonych na wytworzenie produktu.

Za cel główny w pracy przyjęto określenie podstawowych kierunków zmian w organizacji i rentowności produkcji mleka w gospodarstwach wyspecjalizowanych, chrakteryzujących się różnym poziomem całkowitych kosztów wytworzenia mleka. Dodatkowo w badaniach zwrócono uwagę na kształtowanie się podstawowych parametrów produkcyjno-ekonomicznych w gospodarstwach w latach 2012-2016 w Europie.

\section{ŹRÓDłA DANYCH I METODA BADAŃ}

Do badań empirycznych wykorzystano dane gospodarstw należących do Europejskiego Stowarzyszenia Producentów Mleka (EDF - European Dairy Framers) z lat 2012-2016. Do analizy wybrano 124 gospodarstwa, które udostępniały dane w każdym roku okresu badawczego oraz w których produkcja mleka miała charakter konwencjonalny. Do grupy nie zakwalifikowano gospodarstw z Ukrainy oraz Szwajcarii ze względu na odmienność regulacji panujących na rynku rolnym w tych krajach. Zbiorowość podzielono na grupy gospodarstw ze względu na wysokość całkowitych kosztów produkcji mleka ponoszonych w 2012 r., a więc uwzględniających koszty alternatywne własnych czynników produkcji: pracy, ziemi i kapitału. Takie podejście pozwoliło zaobserwować skutki podejmowanych działań w gospodarstwach wykorzystujących zarówno własne, jak i zewnętrzne czynniki produkcji.

Wyniki ekonomiczne gospodarstw ustalono zgodnie z metodyką stosowaną w EDF, która na etapach pośrednich kalkulacji dochodu rolniczego nieznacznie różni się od metodyki FADN (Farm Accountancy Data Network). Koszty bezpośrednie produkcji mleka w metodyce EDF obejmują koszty zakupu zwierząt, koszty związane z usługowym odchowem jałówek, inseminacją, usługami weterynaryjnymi i lekami oraz pozostałe koszty bezpośrednie w produkcji zwierzęcej. Do kosztów bezpośrednich zalicza się również koszty związane z zakupem oraz wytworzeniem pasz własnych (materiał siewny, nawozy, środki ochrony roślin i pozostałe koszty w produkcji pasz) z przeznaczeniem dla zwierząt w produkcji mleka. 
Koszty ogólnogospodarcze oraz koszty czynników produkcji określa się w analogiczny sposób jak w FADN. Natomiast kategoria kosztów całkowitych produkcji mleka to suma kosztów ogółem i kosztów alternatywnych własnych czynników produkcji (ziemi, kapitału i pracy) bez kosztów kwoty mlecznej. Zagadnienie to jest bardzo ważne w przypadku porównań wyników produkcyjno-ekonomicznych gospodarstw, które różnią się pod kątem struktury własności zasobów (ziemi, kapitału i pracy) wykorzystanych do produkcji. W literaturze podejścia do wyceny zaangażowanych zasobów własnych różnią się nieznacznie [Goraj, Mańko 2011, Skarżyńska 2011]. Koszty tzw. utraconych korzyści ustala się tą samą metodą w poszczególnych krajach biorących udział w badaniu. Koszty alternatywne ziemi własnej wykorzystywanej w produkcji mleka ustalono na podstawie czynszu dzierżawnego w regionie działania gospodarstwa. Koszt alternatywny kapitału (bez ziemi) określono na bazie oprocentowania lokat bankowych z terminem pierwotnym powyżej 2 lat dla przedsiębiorstw niefinansowych. Koszty alternatywne rodzinnej siły roboczej szacowano na podstawie iloczynu rocznego nakładu pracy członków rodziny oraz stawek wynagrodzenia (stawki godzinowe kalkulowane były na podstawie rocznych wynagrodzeń brutto w gospodarce narodowej bez premii i nagród).

$\mathrm{W}$ ustaleniu dochodu rolniczego oraz dochodu $\mathrm{z}$ tytułu zarządzania i ryzyka w gałęzi produkcji mleka uwzględniono jedynie koszty, przychody i dopłaty przypisane do tej produkcji. Kategorią dodatkową w diagnozie sytuacji ekonomicznej gospodarstw był dochód z zarządzania z dopłatami niezwiązanymi z produkcją (określone proporcjonalnie do powierzchni paszowej wykorzystywanej w produkcji mleka). W badaniach EDF określa się również progi rentowności w produkcji mleka. Ustalane są one na dwóch poziomach. Pierwszy próg rentowności wyznaczony jest na podstawie kosztów ogółem (suma kosztów bezpośrednich, ogólnogospodarczych, czynników zewnętrznych oraz amortyzacji). Drugi próg rentowności wyznaczony jest przez koszty całkowite wytworzenia mleka (bez kosztów kwoty mlecznej). Obliczenie progów rentowności produkcji mleka opiera się na uproszczeniu, w którym przyjmuje się, że przychody uzyskiwane w produkcji mleka, ale inne niż sprzedaż mleka, mają swoje źródło w działalności pobocznej, a ich wysokość jest równa kosztom wytworzenia sprzedawanych produktów. Progi rentowności w tym przypadku informują o minimalnej cenie mleka, wymaganej do pokrycia kosztów ogółem lub kosztów całkowitych.

\section{CHARAKTERYSTYKA BADANYCH GOSPODARSTW}

W każdym roku analizy badaniom poddano 124 gospodarstwa, z czego 111 było gospodarstwami rodzinnymi, a pozostałe 13 (głównie z Polski, Czech i Słowacji) było zorganizowanych w formie różnego rodzaju spółek. Najliczniej w całej zbiorowości reprezentowane były gospodarstwa holenderskie, szwedzkie oraz belgijskie. Zbiorowość gospodarstw uszeregowano w kolejności rosnącej pod względem całkowitych kosztów produkcji mleka w 2012 r. Następnie dokonano podziału zbiorowości na cztery grupy (po 31 gospodarstw w grupie). W ten sposób utworzono z gospodarstw grupy kwartylowe, w których grupa pierwsza charakteryzowała się najniższymi całkowitymi kosztami produkcji mleka, a w kolejnych grupach koszty były odpowiednio wyższe. Ze względu na cel badań grupy miały charakter stały, co oznacza, że w każdym roku grupy składały się z tych samych podmiotów. Takie podejście pozwoliło na analizę kierunków i siły zmian w gospodarstwach o różnej kondycji ekonomicznej w pierwszym roku analizy (2012 r.). 
Podstawowe dane dotyczące średnich parametrów zbiorowości gospodarstw oraz wydzielonych $\mathrm{z}$ nich grup zaprezentowano w tabeli 1 . Przeciętne koszty całkowite wyprodukowania $100 \mathrm{~kg}$ mleka ECM ${ }^{1}$ w 2012 r. wynosiły 36,3 euro, z czego około 74\% stanowiły koszty ogółem. Najniższe przeciętne koszty ogółem produkcji mleka poniesiono w pierwszej grupie kwartylowej gospodarstw (Q1), były one o 35\% niższe od przeciętnych kosztów z grupy Q4. Podział na grupy ze względu na wysokość kosztów całkowitych produkcji mleka jednoznacznie wskazuje, że gospodarstwa z pierwszego kwartyla charakteryzowały się największym średnim stadem krów oraz najniższą przeciętną wydajnością mleczną krów. Ponadto w gospodarstwach tej grupy zaobserwowano najniższą wartość kapitału w przeliczeniu na krowę. Gospodarstwa z czwartej grupy kwartylowej charakteryzowały się najmniejszą średnią produkcją mleka, co wynikało z najmniejszego średniego stada krów, pomimo najwyższej średniej wydajności mlecznej w porównaniu z pozostałymi grupami

Tabela 1. Podstawowe parametry jako średnie dla grup analizowanych gospodarstw w $2012 \mathrm{r}$.

\begin{tabular}{|c|c|c|c|c|c|}
\hline \multirow[t]{2}{*}{ Wyszczególnienie } & \multirow[t]{2}{*}{ EDF } & \multicolumn{4}{|c|}{ Grupy gospodarstw } \\
\hline & & Q1 & Q2 & Q3 & Q4 \\
\hline $\begin{array}{l}\text { Liczba gospodarstw [szt.] } \\
\text { nar. }\end{array}$ & 124 & 31 & 31 & 31 & 31 \\
\hline $\begin{array}{l}\text { Koszty całkowite produkcji } \\
\text { mleka [euro/100 kg ECM]* }\end{array}$ & 36,3 & 28,1 & 34,2 & 35,9 & 38,54 \\
\hline $\begin{array}{l}\text { Koszty ogółem produkcji } \\
\text { mleka [euro/100 kg ECM] }\end{array}$ & 26,7 & 21,1 & 25,5 & 28,0 & 32,3 \\
\hline $\begin{array}{l}\text { Kraj reprezentowany } \\
\text { najliczniej w grupie } \\
\text { [kraj-liczba gosp.] }\end{array}$ & NL-23 & $\begin{array}{l}\text { DE-7 UK-4 } \\
\text { NL-4 IE-4 }\end{array}$ & $\begin{array}{l}\text { NL-6 ES-5 } \\
\text { BE-4 FR-4 }\end{array}$ & $\begin{array}{l}\text { NL-9 } \\
\text { SE-4 }\end{array}$ & $\begin{array}{l}\text { SE-8 NL-4 } \\
\text { BE-5 FR-5 }\end{array}$ \\
\hline $\begin{array}{l}\text { Pogłowie krów mlecznych } \\
\text { [szt./gosp.] }\end{array}$ & 216 & 275 & 206 & 209 & 174 \\
\hline $\begin{array}{l}\text { Wydajność mleczna } \\
{[\mathrm{kg} / \text { krowę }]}\end{array}$ & 8884 & 8404 & 9110 & 8894 & 9129 \\
\hline Zawartość białka [\%] & 3,41 & 3,41 & 3,43 & 3,40 & 3,41 \\
\hline Zawartość tłuszczu [\%] & 4,10 & 4,08 & 4,04 & 4,15 & 4,13 \\
\hline Produkcja mleka [t ECM/rok] & 1967 & 2473 & 1890 & 1898 & 1607 \\
\hline $\begin{array}{l}\text { Obsada zwierząt } \\
\text { [SD/1 ha powierzchni } \\
\text { paszowej] }\end{array}$ & 1,77 & 1,74 & 2,03 & 1,86 & 1,45 \\
\hline $\begin{array}{l}\text { Udział powierzchni paszowej } \\
\text { dzierżawionej [\%] }\end{array}$ & 53,2 & 57,6 & 56,7 & 37,7 & 60,6 \\
\hline $\begin{array}{l}\text { Nakład pracy (własnej i } \\
\text { najemnej) na krowę [h/krowa] }\end{array}$ & 44,1 & 44,6 & 44,1 & 40,0 & 47,7 \\
\hline $\begin{array}{l}\text { Średnia wartość kapitału } \\
\text { na } 1 \text { krowę [tys. euro/SD] }\end{array}$ & 6351 & 4323 & 5665 & 6011 & 9404 \\
\hline
\end{tabular}

* Kurs wymiany 1 euro według NBP w 2012 r. 4,1850 zł, w 2013 r. 4,1975 zł, w 2014 r. 4,1852 zł, w 2015 r. 4,1839 zł, w 2016 r. 4,3625 zł.

Wyjaśnienia skrótów nazw krajów: NL - Holandia, SE - Szwecja, BE - Belgia, DE - Niemcy, FR - Francja, ES - Hiszpania, DK - Dania, UK - Wielka Brytania, IE - Irlandia, pozostałe (liczba gospodarstw): Włochy (1), Polska (3), Portugalia (3), Słowacja (3), Czechy (2).

Zródło: obliczenia własne na podstawie danych EDF.

1 ECM to mleko o skorygowanej zawartości energii (białko 3,3\% i tłuszcz 4,0\%). 
gospodarstw. W przeliczeniu na 1 krowę przeciętny poziom zaangażowanego kapitału w tej grupie był najwyższy i wyraźnie odbiegał wartością od pozostałych grup gospodarstw. Dodatkowo czwarty kwartyl gospodarstw charakteryzował się najniższą przeciętną obsadą zwierząt oraz największym udziałem dzierżawionej powierzchni w powierzchni paszowej.

\section{PRODUKCJA MLEKA ORAZ ZMIANY W JEJ ORGANIZACJI W GOSPODARSTWACH EDF}

Produkcja mleka w gospodarstwach w badanym okresie zwiększyła się. Przeciętnie w całej zbiorowości co roku wytwarzano o około 6\% mleka więcej (rys. 1.), co w konsekwencji w 2016 r. doprowadziło do wzrostu produkcji o około $1 / 4 \mathrm{~W}$ porównaniu z $2012 \mathrm{r}$. Wzrost ten wynikał przede wszystkim ze zwiększania liczebności stad krów (w całej zbiorowości wzrost przeciętnej liczby krów wynosił 19\%). Najwyższym tempem wzrostu pogłowia charakteryzował się drugi kwartyl zbiorowości Q2, w którym od 2012 r. przeciętne stado zwiększyło się o $1 / 4$ (wzrost średnio o 52 szt. w gospodarstwie). W 2016 r. przeciętne stado liczyło 258 krów. Nieco niższy liczbowy wzrost nastąpił w pierwszej grupie gospodarstw Q1 (46 szt.), w ujęciu procentowym wzrost ten był najniższy (o 17\%) i w 2016 r. średnio w gospodarstwach utrzymywano 321 krów. Wydajność mleczna krów do 2016 r. w całej zbiorowości wzrosła przeciętnie o około 5\%, przyrost ten szczególnie uwidocznił się w ostatnim roku, w którym wynosił $\%$ w stosunku do roku 2015. Najwyższy wzrost wydajności mlecznej krów zaobserwowano w grupie Q3 o około 7\%. W efekcie zmian wielkości stada i wydajności mlecznej przeciętna produkcja mleka w gospodarstwach w 2016 r. wynosiła prawie 2,5 tys. t, a różnica między produkcją w grupach Q1 i Q4 wynosiła około 1000 t ECM rocznie.

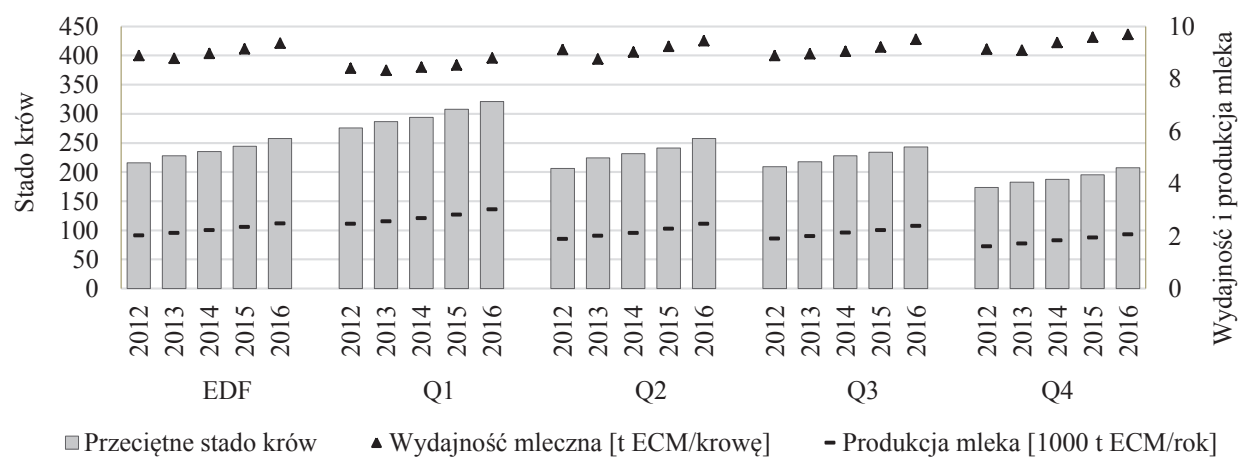

Rysunek 1. Wielkość stada, wydajność mleczna krów oraz produkcja mleka w gospodarstwach w latach 2012-2016

Źródło: obliczenia własne na podstawie danych EDF.

Poziom wydajności mlecznej krów wynika z wielu uwarunkowań. Do podstawowych czynników, oprócz genetycznych, można zaliczyć czynniki środowiskowe, związane m.in. z żywieniem krów. Przeciętne dzienne zużycie pasz treściwych w zbiorowości w 2012 r. kształtowało się na poziomie około 7,5 kg dziennie na 1 krowę (rys. 2.).

W 2016 roku zaobserwowano nieco wyższy wzrost zużycia pasz treściwych w większości grup (średnio o 0,3 kg na krowę), co może mieć związek ze stwierdzonym wzro- 


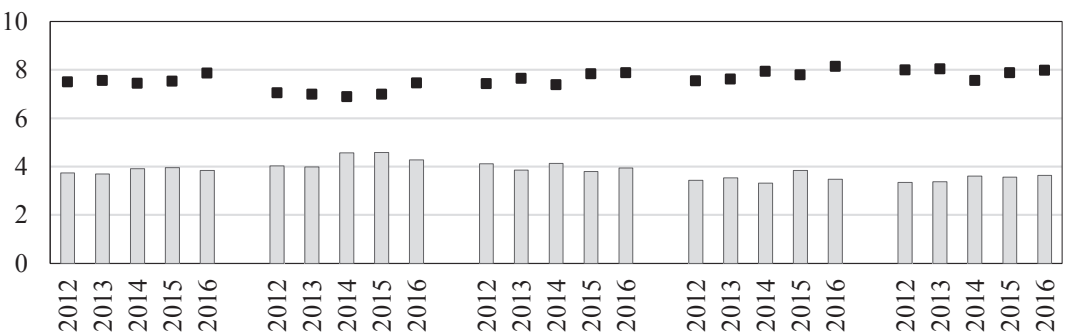

$\begin{array}{lllll}\text { EDF } & \text { Q1 } & \text { Q2 } & \text { Q3 } & \text { Q4 }\end{array}$

$\square$ Produktywność żywienia paszą treściwą [kg ECM/ kg]

- Zużycie pasz treściwych [kg/dzień/krowę]

Rysunek 2. Produktywność i zużycie pasz treściwych w gospodarstwach w latach 2012-2016 Źródło: obliczenia własne na podstawie danych EDF.

stem wydajności mlecznej krów. Wyższa wydajność mleczna krów wiąże się z większym udziałem pasz treściwych w dawce żywieniowej, a zatem i ich zużyciem. Produktywność żywienia paszą treściwą uległa poprawie (o 3\% w porównaniu z rokiem 2012), jednak charakteryzowała się dużą zmiennością. Najwyższą produktywność żywienia paszą treściwą osiągnęły podmioty z grupy Q1, w których z $1 \mathrm{~kg}$ paszy wytwarzano w ostatnich trzech latach analizy powyżej $4 \mathrm{~kg}$ mleka.

Na poziom wydajności mlecznej krów, oprócz żywienia, mogą wpłynąć również czynniki związane z zarządzaniem stadem, np. wiek pierwszego wycielenia oraz okres międzywycieleniowy. Trudno precyzyjnie określić najbardziej optymalny wiek pierwszego wycielenia, zarówno z perspektywy wydajności mlecznej w pierwszej laktacji, jak i drugiej i trzeciej [Sitkowska $i$ in. 2009]. W badanej zbiorowości najwcześniej po raz pierwszy cieliły się jałówki w gospodarstwach z pierwszego kwartyla (czyli w gospodarstwach o niższej wydajności mlecznej), natomiast w gospodarstwach kwartyla czwartego wiek ten był najwyższy (tab. 2.). Warto jednak zauważyć, że wiek ten w gospodarstwach z najwyższą wydajnością (Q4) w kolejnych latach uległ obniżeniu (w 2016 r. o niecałe 2 tygodnie). W całej zbiorowości przeciętny wiek pierwszego wycielenia w analizowanym okresie skrócił się o około 4 dni.

Za prawidłową długość okresu międzywycieleniowego (OMW) uznaje się 360-400 dni [Juszczak, Hibner 2000, Czaplicka i in. 2003], w gospodarstwach wydłuża się go w

Tabela 2. Wybrane parametry zarządzania stadem w gospodarstwach w latach 2012-2016 r.

\begin{tabular}{|c|c|c|c|c|c|c|c|c|c|c|c|c|c|c|c|}
\hline \multirow[t]{2}{*}{ Lata } & \multicolumn{5}{|c|}{$\begin{array}{c}\text { Wiek pierwszego } \\
\text { wycielenia [miesiące] }\end{array}$} & \multicolumn{5}{|c|}{$\begin{array}{c}\text { Okres międzywycieleniowy } \\
\text { [dni] }\end{array}$} & \multicolumn{5}{|c|}{$\begin{array}{c}\text { Brakowanie krów } \\
{[\%]}\end{array}$} \\
\hline & EDF & Q1 & Q2 & Q3 & Q4 & EDF & Q1 & Q2 & Q3 & Q4 & EDF & Q1 & Q2 & Q3 & Q4 \\
\hline 2012 & 25,7 & 25,4 & 25,5 & 25,8 & 26,2 & 405 & 406 & 400 & 406 & 408 & 29,6 & 26,1 & 28,0 & 28,8 & 35,4 \\
\hline 2013 & 25,8 & 25,4 & 5,7 & 25,8 & 26,2 & 405 & 405 & 401 & 408 & 406 & 27,5 & 23,2 & 25,7 & 30,0 & \\
\hline 2014 & 25,6 & 25,2 & 25,5 & 25,6 & 26,1 & 401 & 406 & 398 & 399 & 401 & 29,3 & 26,4 & 30,9 & 28,5 & 31 \\
\hline 2015 & 25,5 & 25,0 & 25,4 & 25,6 & 26,0 & 401 & 405 & 399 & 399 & 402 & 28,1 & 25,0 & 28,1 & 28,3 & 31,1 \\
\hline 2016 & 25,6 & 25,3 & 25,8 & 25,7 & 25,8 & 400 & 405 & 397 & 399 & 399 & 29,3 & 27,9 & 29,3 & 27,8 & 32,1 \\
\hline
\end{tabular}

Źródło: opracowanie własne na podstawie danych EDF. 
celu pełniejszego wykorzystania potencjału produkcyjnego krów w czasie dłuższej laktacji [Hibner i in. 1999]. Okres międzywycieleniowy w badanej zbiorowości nie potwierdzał wyników badań, wskazujących, że wysokiej wydajności mlecznej krów towarzyszy wydłużony okres międzywycieleniowy [Gil i in. 2007, Winnicki i in. 2007]. W 2016 r. najdłuższym okresem międzywycieleniowym (405 dni) charakteryzowały się gospodarstwa z grupy Q1, a więc te, które osiągnęły przeciętnie najniższą wydajność mleczną krów spośród analizowanych podmiotów. Przeciętny okres międzywycieleniowy w całej zbiorowości charakteryzował się tendencją malejącą, zmniejszył się z 405 do 400 dni.

Realizacja strategii wzrostu produkcji w gospodarstwach skutkowała również zmianami w brakowaniu zwierząt. Tendencją malejącą w brakowaniu krów charakteryzowały się gospodarstwa z trzeciego i czwartego kwartyla. Zwiększenie brakowania szczególnie w ostatnim roku występowało w dwóch pierwszych kwartylach zbiorowości. Wysokie brakowanie krów jest zjawiskiem charakterystycznym dla gospodarstw o wysokiej wydajności mlecznej krów, co miało swoje odzwierciedlenie w prezentowanych wynikach. Różnica w brakowaniu krów w 2016 r. pomiędzy grupą o najwyższej i najniższej wydajności mlecznej (grup Q4 i Q1) wynosiła 4,2 p.p. Wzrost brakowania w 2016 r. w większości grup gospodarstw był wywołany chęcią eliminacji sztuk o niższej wydajności mlecznej w okresie niskich cen na mleko.

Nakłady czynników produkcji, zarówno w całej zbiorowości, jak i w poszczególnych grupach gospodarstw, w przeważającej liczbie obserwacji charakteryzowały się tendencją rosnącą (tab. 3.). Zwiększaniu stad krów w gospodarstwach towarzyszyło przeważnie powiększanie powierzchni paszowej, która przeciętnie wzrosła o 13 ha (9\%). Ograniczenie powierzchni paszowej zaobserwowano w grupie Q1, w porównaniu z 2012 r. powierzchnia wykorzystywana w produkcji mleka była mniejsza o około 8 ha. W pozostałych grupach na produkcję pasz przeznaczano większą powierzchnię niż w 2012 r. od 14 do 24 ha. Najwyższą obsadą zwierząt oraz produktywnością ziemi charakteryzowały się gospodarstwa z grup Q2 i Q3. Natomiast intensywność wykorzystania ziemi w gospodarstwach z grup Q4 i Q1 była niższa - z 1 ha powierzchni paszowej wytwarzano rocznie prawie $15 \mathrm{t}$ mleka. Gospodarstwa z tej grupy osiągały produktywność niższą niż gospodarstwa w grupie Q2 o około 5 t mleka/ha. Przeciętna produktywność ziemi charakteryzowała się jednak tendencją rosnącą w całej zbiorowości.

Czynnikiem produkcji, który w analizowanym okresie gospodarstwa powszechnie zwiększały, był kapitał. Jego średnia wartość wykorzystywana w produkcji mleka zwiększyła się o ponad $20 \%$ do 2016 r., czyli o około 300 tys. euro. Najwyższy wzrost kapitału w analizowanym okresie zaobserwowano w grupie Q2. Do 2016 r. kapitał ten wzrósł o ponad pół miliona euro (46\%). Uwzględniając przeciętną wielkość stada krów należy zauważyć, że w gospodarstwach widoczna była dysproporcja w kapitale przypadającym na zwierzę. Przeciętnie wartość ta wynosiła w 2016 r. prawie 7 tys. euro, przy czym nakład kapitału w grupie Q1 był o około 1,6 tys. euro niższy od średniego w zbiorowości, a w grupie Q4 o 1,8 tys. wyższy. Dysproporcje utrzymywały się również w produktywności kapitału w gospodarstwach. Przeciętnie w całej zbiorowości w 2016 r. zaangażowanie 1000 euro w produkcję mleka pozwalało na wyprodukowanie około 1,7 t ECM. W grupie gospodarstw o najniższych kosztach całkowitych (Q1) produktywność była o 0,37 t ECM wyższa niż średnio w zbiorowości, a w grupie Q4 o 0,36 t ECM niższa. Ponadto, w analizowanym okresie przeciętna produktywność kapitału w zbiorowości gospodarstw malała, co oznacza, że tempo wzrostu produkcji w gospodarstwach było niższe niż tempo wzrostu zaangażowania kapitału w tę produkcję. 


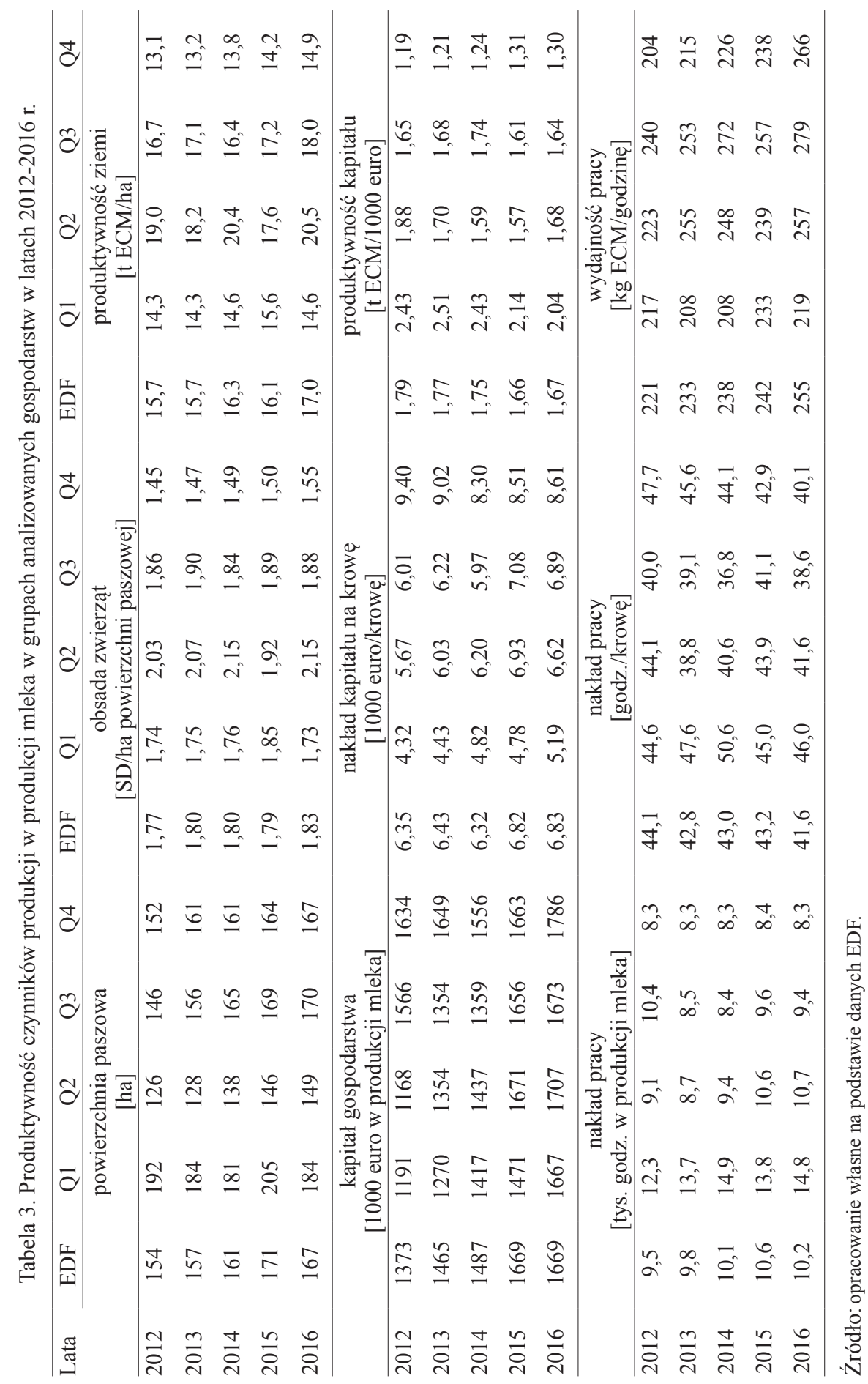


Całkowite nakłady pracy w produkcji mleka w analizowanych grupach wzrosły do 2016 r. przeciętnie o 7\%, przy czym wykorzystanie zasobów pracy wyraźnie zwiększyło się w grupie Q1 (wzrost o 20\% w stosunku do 2012 r.), natomiast w grupie Q3 uległo zmniejszeniu o $10 \%$ (1000 h), a w grupie Q4 pozostało na stabilnym poziomie 8,3 tys. godzin. Gospodarstwa w większości grup (z wyjątkiem grupy Q1) zracjonalizowały wykorzystanie zasobów pracy, które przy wzroście stada w przeliczeniu na 1 krowę zmniejszyły się (najbardziej w grupie Q4 o prawie $8 \mathrm{~h}$ na zwierzę w roku). Takie działania poprawiły wydajność pracy, która w zbiorowości wzrosła średnio o 16\%. W grupie Q4 w 2016 r. w każdej zaangażowanej godzinie pracy produkcja mleka była wyższa o $61 \mathrm{~kg}$ mleka niż w 2012 r. W gospodarstwach z grupy Q1 wzrost nakładów pracy przy jednoczesnym wzroście produkcji mleka spowodował utrzymanie się wydajności pracy na stabilnym poziomie, około $219 \mathrm{~kg}$ mleka na godzinę pracy.

\section{OPŁACALNOŚĆ PRODUKCJI MLEKA W GOSPODARSTWACH}

Sprzedaż mleka stanowiła w gospodarstwach nie mniej niż 83\% sumy przychodów w produkcji mleka. Średnie przychody ze sprzedaży mleka w poszczególnych grupach gospodarstw kształtowały się na podobnym poziomie (rys. 3.). Wskazuje to na nieznaczne zróżnicowanie cen mleka w poszczególnych grupach gospodarstw. Od 2012 r. do 2014 r. ceny, a zatem i przychody ze sprzedaży $100 \mathrm{~kg}$ mleka, wzrosły z około 34 do 39 euro. W kolejnych latach nastąpił ich spadek do poziomu około 29 euro w 2016 r., czyli o około $25 \%$. Spadek ten stał się główną przyczyną zmniejszenia przychodów całkowitych w gospodarstwach. Ich najniższy poziom w przeliczeniu na $100 \mathrm{~kg}$ mleka w $2016 \mathrm{r}$. wystąpił w gospodarstwach z pierwszej grupy kwartylowej i wynosił 33 euro, najwyższy zaś osiągnęły gospodarstwa w grupie Q4, na poziomie około 35,5 euro.

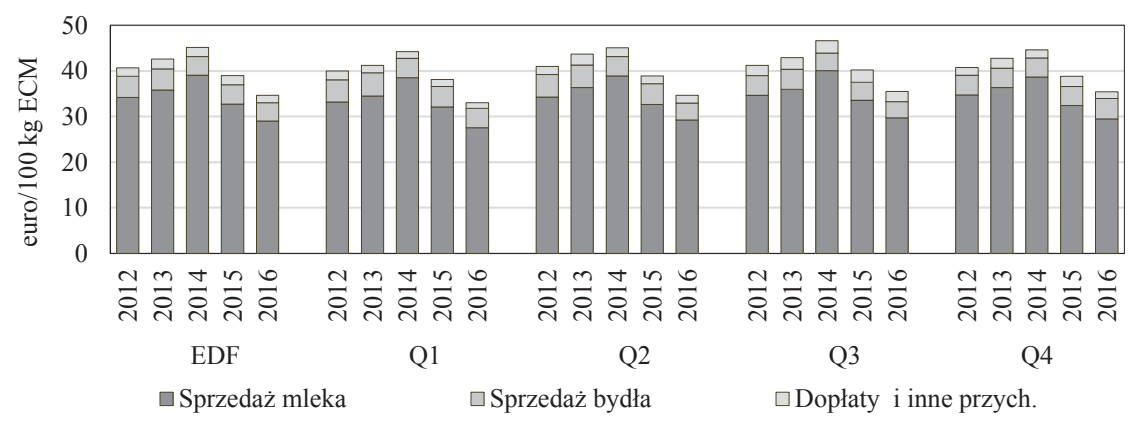

Rysunek 3. Przychody w produkcji mleka w gospodarstwach EDF Źródło: obliczenia własne na podstawie danych EDF.

Kształtowanie się oraz poziom kosztów całkowitych i ich składników był zdecydowanie bardziej zróżnicowany niż w przypadku przychodów w produkcji mleka (rys. 4.). Przeciętne koszty całkowite produkcji w 2016 r. w całej zbiorowości wynosiły 40 euro i były niższe o 8\% niż w 2012 r. W 1. kwartylu zbiorowości koszty te w 2016 r. były niższe o ponad 8 euro niż w grupie Q4. Różnica w przeciętnych kosztach między tymi grupami podmiotów w zestawieniu z rokiem 2012 zmniejszyła się o 8 euro na $100 \mathrm{~kg}$ ECM (w $2012 \mathrm{r}$. różnica na niekorzyść grupy Q4 wynosiła 16 euro). We wszystkich grupach gospodarstw 


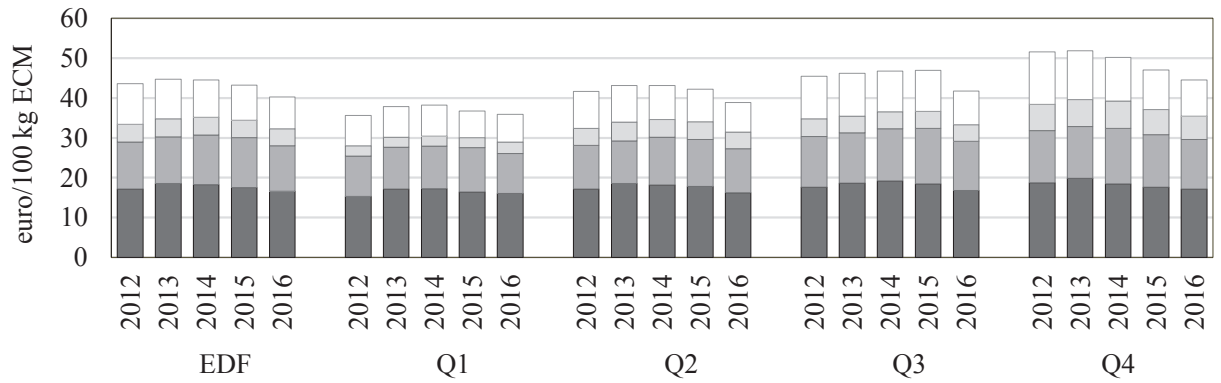

$\square$ Koszty alternatywne $\square$ Amortyzacja $\square$ Koszty ogólnogosp. i czynników prod. $\square$ Koszty bezpośrednie

Rysunek 4. Koszty całkowite w produkcji mleka

Źródło: obliczenia własne na podstawie danych EDF.

można zaobserwować obniżenie kosztów bezpośrednich zapoczątkowane w większości grup od 2013 r., jednak najbardziej widoczne w 2016 r. (szczególnie w grupach Q2 i Q3). Gospodarstwa głównie ograniczyły koszty ponoszone na zakup pasz i koszty związane z ich produkcją (koszty nawozów). Ograniczeniu uległy również pozostałe koszty w produkcji mleka i pozostałe koszty w produkcji pasz. Największe różnice w poszczególnych kategoriach kosztów pomiędzy grupami można zaobserwować w amortyzacji i kosztach alternatywnych. W 2016 r. w grupie Q4 suma tych dwóch kategorii kosztowych była o 50\% wyższa niż w gospodarstwach z grupy Q1. Poziom kosztów rzeczywistych (bezpośrednich, ogólnogospodarczych oraz czynników produkcji) w poszczególnych grupach różnił się zdecydowanie mniej. Rozstęp ich wartości wynosił 2,8 euro, na korzyść grupy Q1 (niższe koszty rzeczywiste niż średnie w zbiorowości).

Sytuacja dochodowa w grupach gospodarstw była zróżnicowana (rys. 5.). W badanym okresie koszty ogółem ponoszone w produkcji mleka były pokrywane przez przychody w niej uzyskiwane. Do 2014 r. dochód rolniczy charakteryzował się tendencją rosnącą, ale w kolejnych latach przyjmował wartości zdecydowanie niższe. Wyniki dodatkowo charakteryzowały się dużym zróżnicowaniem między grupami gospodarstw. W 2016 r. przeciętny dochód rolniczy w grupie Q4 wynosił 0,01 euro na $100 \mathrm{~kg}$ mleka (w przeliczeniu na całą produkcję mleka stanowiło to dochód w wysokości 300 euro). Natomiast

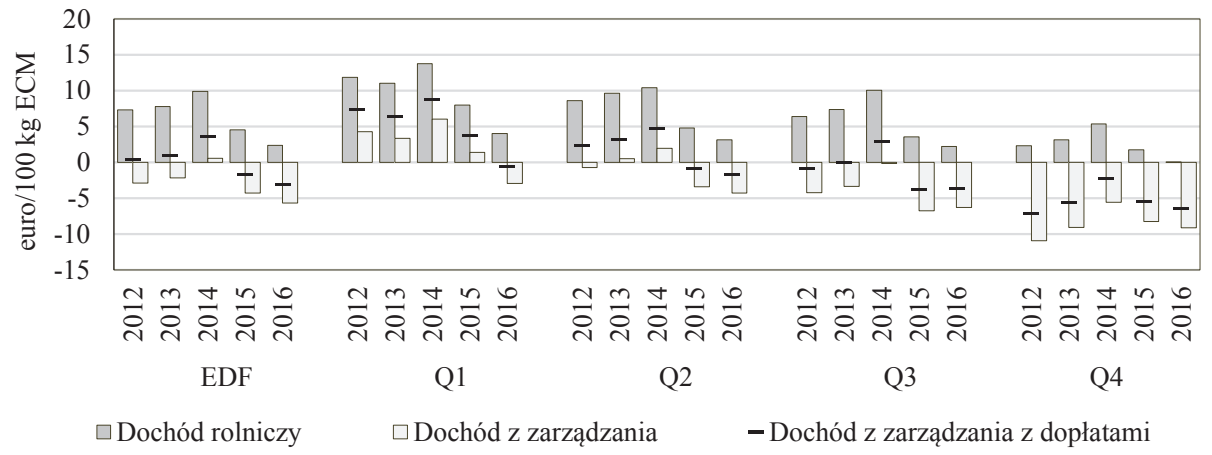

Rysunek 5. Dochody w produkcji mleka w grupach gospodarstw Źródło: obliczenia własne na podstawie danych EDF. 
w grupie Q1 wyprodukowanie 100 kg mleka pozwoliło uzyskać dochód w wysokości 4,1 euro (w przeliczeniu na całą produkcję wynosił on 122 tys. euro). Gospodarstwa w 2016 r., czyli w okresie największego spadku przychodów, nie były w stanie pokryć kosztów alternatywnych własnych czynników produkcji (ziemi, kapitału i pracy). Dochód z tytułu zarządzania we wszystkich grupach gospodarstw przyjmował wówczas wartości ujemne, co oznacza, że wykorzystanie własnych czynników produkcji w innych celach niż produkcja mleka pozwoliłoby na uniknięcie straty. W grupie Q1 dochód z tytułu zarządzania osiągany był do 2015 r., dopiero w 2016 r. przyjął on wartości ujemne i wynosił -3 euro na $100 \mathrm{~kg}$ ECM (w przeliczeniu na gospodarstwo straty wynosiły około 9,5 tys. euro, a po uwzględnieniu dopłat strata zmniejszyła się do poziomu 2 tys.). W pozostałych grupach gospodarstw straty z tytułu zarządzania były zdecydowanie większe. W grupie Q2 i Q3 od 2015 r., a w grupie Q4 od 2012 roku w produkcji mleka nie osiągano dochodów z tytułu zarządzania nawet po uwzględnieniu dopłat niezwiązanych z produkcją).

Uwzględnienie $\mathrm{w}$ analizie jedynie kosztów produkcji mleka oraz ich zestawienie $\mathrm{z}$ uzyskiwanymi cenami na produkt dało możliwość oceny rentowności tej produkcji (rys. 6.). W analizowanym okresie we wszystkich grupach osiągnięto pierwszy próg rentowności. Oznacza to, że koszty bezpośrednie, ogólnogospodarcze, czynników zewnętrznych oraz amortyzacji związane z wytworzeniem mleka pokrywano uzyskiwaną ceną mleka. Jednocześnie różnica między ceną mleka a kosztami ogółem jego wytworzenia nie pozwalała, w większości gospodarstw i przeważającej liczbie lat, pokryć kosztów wykorzystania własnych czynników produkcji. Sytuacja taka nastąpiła we wszystkich grupach gospodarstw w 2016 r. Z całej zbiorowości zaledwie w 15 gospodarstwach osiągnięto drugi próg rentowności (z tego w 7 gospodarstwach z pierwszej grupy kwartylowej). Strata wynikająca z wyższych kosztów całkowitych wytworzenia mleka od uzyskiwanych cen na mleko kształtowała się od około 3 euro w grupie Q1 do około 9 euro w grupie Q4 na każde 100 kg ECM. Utrzymywała się przewaga gospodarstw z pierwszego kwartyla zbiorowości pod względem całkowitych kosztów produkcji mleka. W porównaniu z grupą Q4 koszty te były niższe o ponad $1 / 4(26 \%)$, co przy kształtujących się na dość podobnym poziomie cenach mleka we wszystkich grupach gospodarstw pozwoliło tym podmiotom na osiąganie najwyższej rentowności w latach 2012-2015 oraz na najmniejszą stratę w 2016 r.

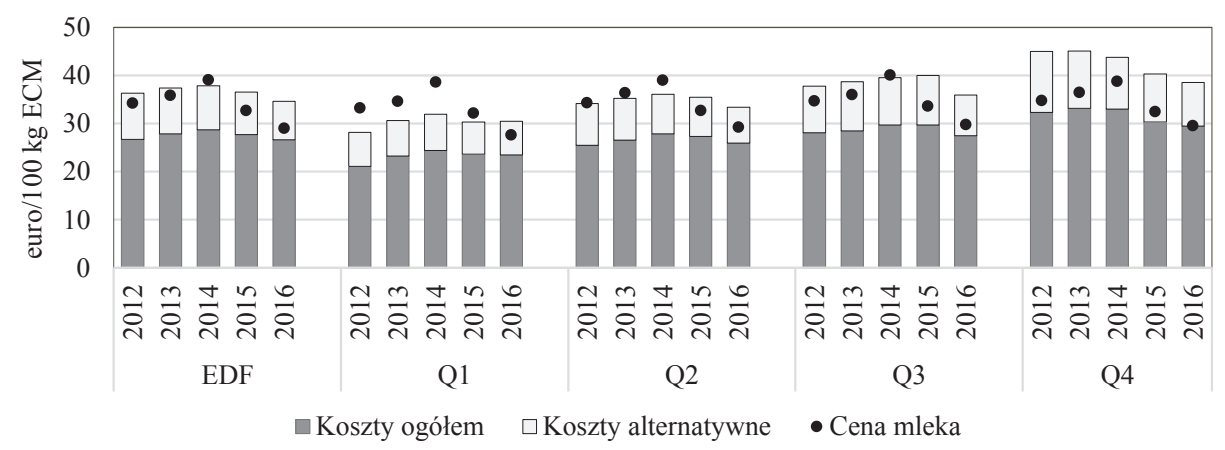

Rysunek 6. Progi rentowności w produkcji mleka Źródło: obliczenia własne na podstawie danych EDF. 


\section{PODSUMOWANIE}

Analizę zmian organizacyjnych oraz ekonomicznych przeprowadzono w wybranych gospodarstwach wyspecjalizowanych w produkcji mleka w Europie. Badania dotyczyły tej samej próby gospodarstw działających w okresie deregulacji europejskiego rynku mleka w latach 2012-2016. Wyniki badań odzwierciedlają podstawowe kierunki zmian w obszarze organizacji i opłacalności produkcji mleka w gospodarstwach połączonych $\mathrm{w}$ grupy ze względu na poziom kosztów całkowitych wytwarzania mleka.

Przeprowadzone badania wskazują, że $25 \%$ gospodarstw z badanej próby, o najniższych kosztach całkowitych produkcji mleka, charakteryzowało się zdecydowanie liczniejszymi stadami krów przy jednocześnie niższej wydajności mlecznej w próbie. W latach 2012$2016 \mathrm{w}$ analizowanych gospodarstwach dążono do wzrostu produkcji, zarówno w okresach wzrostu, jak i spadku cen. W gospodarstwach o niższych kosztach całkowitych wzrost produkcji w większym stopniu wynikał ze zwiększania liczby krów w stadzie, natomiast gospodarstwa trzeciego i czwartego kwartyla próby w większym stopniu koncentrowały się na wzroście wydajności mlecznej krów, co miało odzwierciedlenie w nakładach w produkcji oraz kształtowaniu się parametrów zarządzania stadem. Zwiększenie produkcji wywołało zmiany w produktywności czynników produkcji. Zwiększyła się intensywność wykorzystania powierzchni paszowej i zasobów pracy. Pogorszyła się zaś produktywność kapitału. Zwiększenie jego wykorzystywania w produkcji mleka nie przełożyło się na wystarczające zwiększenie produkcji mleka, pozwalające na utrzymanie lub wzrost produktywności kapitału w trzech kwartylach zbiorowości w stosunku do roku wyjściowego.

Zwiększenie produkcji mleka w gospodarstwach przy dosyć niestabilnym poziomie cen mleka miało przełożenie na opłacalność jego wytwarzania. W kontekście opłacalności produkcji dużą rolę odegrały koszty produkcji mleka. Takie twierdzenie wynika z braku wyraźnego zróżnicowania poziomu cen między grupami analizowanych gospodarstw. W kształtowaniu się poziomu kosztów we wszystkich grupach obserwowano tendencję do ich zmniejszania, zwłaszcza w sytuacji głębokiego spadku cen w 2016 r. Wyniki wyraźnie wskazują, że zmniejszały się różnice w poziomie ponoszonych kosztów, zwłaszcza w obszarze kosztów bezpośrednich. Jednocześnie największe dysproporcje występowały w amortyzacji i kosztach alternatywnych, czyli kosztach, które nie wiązały się z rzeczywistym wypływem środków pieniężnych z gospodarstwa. Na podstawie kosztów ogółem można stwierdzić, że produkcja mleka w latach 2012-2016 była rentowna w gospodarstwach (poza 2016 r. w grupie Q4). Jednak w zdecydowanej większości gospodarstw wygospodarowany dochód rolniczy nie osiągnął poziomu wystarczającego do pokrycia kosztów alternatywnych w produkcji mleka, zwłaszcza w $2016 \mathrm{r}$. Należy podkreślić, że grupa gospodarstw z najniższymi kosztami całkowitymi produkcji utrzymywała przewagę w opłacalności nad gospodarstwami z pozostałych grup, przy czym dystans w poziomie ponoszonych kosztów między grupami ulegał zmniejszeniu.

\section{LITERATURA}

Brodzińska Katarzyna, 2016: Problemy funkcjonowania i rozwoju rodzinnych gospodarstw mlecznych w Polsce na tle uwarunkowań światowych, „Problemy Rolnictwa Światowego”, t. 16, z. 3, p. 29-38.

Czaplicka Maria, Zbigniew Puchajda, Tomasz Szalunas, 2003: Porównanie dlugości laktacji, okresu międzywycieleniowego oraz wydajności mleka $w$ czterech laktacjach krów importowanych $z$ Francji i krajowych c. b., „Zeszyty Naukowe PTZ, Przegląd Hodowlany”, t. 68, z. 1, p. 107-114.

European Commission, 2014: Short Term Outlook for the EU arable crops, meat and dairy markets in 2014 and 2015. Directorate General for Agriculture and Rural Development, Brussels, p. 16. 
European Commission, 2017: EU Milk Market Observatory. Directorate General for Agriculture and Rural Development, Brussels. https://ec.europa.eu/agriculture/market-observatory/milk en.

Gil Zygmunt, Andrzej Felenczak, Justyna Żychlińska-Buczek, Kinga Siatka, 2007: Zależność między wydajnościa mleczna krów a wskaźnikami reprodukcji krów, „Medycyna weterynaryjna”, t. 63, z. 3, s. 333-335.

Goraj Lech, Stanisław Mańko, 2011: Model szacowania petnych kosztów działalności gospodarstw rolnych, „Zagadnienia Ekonomiki Rolnej”, nr 3, s. 28-58.

Grochowska Renata, 2017: Niespójność dziatań interwencyjnych na unijnym rynku mleka, „Problemy Rolnictwa Światowego", t. 17, z. 3, p. 93-100.

Hemme Torsten (red.), 2017: IFCN Dairy Report 2017. International Farm Comparison Network, Kiel, p. 17.

Hemme Torsten (red.), 2016: IFCN Dairy Report 2016. International Farm Comparison Network, Kiel, p. 68.

Hibner Andrzej, Andrzej Zachwieja, Jerzy Juszczak, Ryszard Ziemiński, 1999: Efektywność produkcji mleka $w$ stadach wysokowydajnych $w$ aspekcie zróżnicowanej dlugości cyklu reprodukcyjnego krów, „Medycyna Weterynaryjna”, t. 55, z. 11, s. 753-756.

Juszczak Jerzy, Andrzej Hibner, 2000: Biologiczny okres spoczynku rozrodczego w świetle badań nad efektywnościa użytkowania mlecznego krów, „Zeszyty Naukowe PTZ, Przegląd Hodowlany”, t. 51, s. 101-108.

Kołoszycz Ewa, 2016: Światowy rynek mleka - wybrane zagadnienia, „Prace Naukowe Uniwersytetu Ekonomicznego we Wrocławiu. Polityka Ekonomiczna, z. 450, s. 287-297.

Krammer Monica, Manuela Larcher, Stefan Vogel, Erwin Lautsch, 2012: The pattern of Austrian dairy farm houshold strategies, "German Journal of Agriculture Economics", t. 61, z. 2, p. 96-113.

Sitkowska Beata, Sławomir Mroczkowski, Agata Topolewska, 2009: Wptyw wieku pierwszego wycielenia oraz dlugości okresu międzywycieleniowego na produkcyjność mleczna krów, „Zeszyty Naukowe nr 252, Zootechnika", t. 37, s. 99-107.

Skarżyńska Aldona 201:. Koszty ekonomiczne produkcji mleka - metodyczne ujęcie rachunku oraz wyniki badań w 2009 roku. „Zagadnienia Ekonomiki Rolnej”, nr 3, s. 143-161.

Winnicki Stanisław, Romana Głowicka-Wołoszyn, 2007: Wydajność mleczna krów o przedlużonej laktacji, „Roczniki Nauk Zootechniki. Suplement”, nr 23, s. 59-62.

\title{
Ewa Kołoszycz \\ ECONOMIC AND ORGANIZATIONAL CHANGES IN DAIRY FARMS MEMBERS \\ OF THE EUROPEAN DAIRY FARMERS
}

\begin{abstract}
Summary
The paper aims to discussion of the changes that have been made in farms specialised in milk production in the period before and after changes the dairy market in Europe. To research is based on the selected 124 farm belonging to the European Dairy Farmers (EDF), which in period 2012-2016 participated in the analysis of the cost of milk production. There were examined changes in the organization of production, used resources, and the economic effects on farms. The results indicate that all groups of farms have increased their milk production, resulting from the growth of both the multiplicity of cow herds as well as with the improvement of milk yield. It has been observed an increase in the intensity of land use and labor, and has worsened the productivity of capital involved in dairy production. The biggest differences between the groups in the incurred costs in milk production were in the opportunity cost and depreciation. Unfavorable price situation on the market in 2016 resulted in the situation that, the total cost of milk production were lower than the prices of milk only by $12 \%$ in the analysed farms.
\end{abstract}

Adres do korespondencji: Dr Ewa Kołoszycz

Zachodniopomorski Uniwersytet Technologiczny w Szczecinie Katedra Zarządzania Przedsiębiorstwami ul. K. Janickiego 31, 71-270 Szczecin e-mail: ewa.koloszycz@zut.edu.pl 